\title{
A Dark Green Religious Analysis of the Life and Work of Wangari Maathai (1940 - 2011)
}

\section{Louisa Johanna (Hannelie) du Toit ${ }^{1}$}

\begin{abstract}
${ }^{1}$ SHORT BIO
Louisa Johanna (Hannelie) du Toit is a PhD candidate in the Department of Religion Studies at the University of Johannesburg, South Africa. Her background is in biochemistry and food science and she is interested in the interface between religion and science, and the discipline of eco-theology. Her research is focused on the worsening global environmental crisis and the response of society, especially religious society, in addressing it.
\end{abstract}

\section{INSTITUTIONAL AFFILIATION}

Department of Religion Studies, University of Johannesburg, South

Africa; dutoit.hannelie410@gmail.com

ORCID

https://orcid.org/0000-0003-1691-8652

\begin{abstract}
Dark Green Religion (DGR), is an umbrella term formulated by Bron Taylor, to describe nature revering movements that do not fit into the category of organized religion. These movements use religious-like emotions to express their convictions and display a sincere commitment towards the environment. A central focus of DGR is a deep-felt kinship with all living organisms on Earth (arising from a Darwinian understanding that all forms of life have developed from a common ancestor), accompanied by feelings of humility coupled with a critical view of human moral superiority. This article presents a Dark Green Religious analysis of the life and work of Wangari Maathai (1940-2011). She was the first woman in East Africa to receive a doctorate, and was awarded the Nobel Peace Prize in 2004 for her work with the Green Belt Movement (GBM). In the DGR analysis, it is illustrated that the principles of belonging, interconnectedness and sacredness are revealed through Maathai's written legacy. Evidence is also presented that she could be viewed as an example of Naturalistic Gaianism, one of the four types of DGR. In conclusion, a link between ecofeminism and DGR is proposed by highlighting the shared concepts between the two phenomena.
\end{abstract}

\section{KEYWORDS}

Belonging, Dark Green Religion, environmental crisis, Gaian Naturalism, Green Belt Movement, Wangari Maathai.

\section{Introduction}

This article focuses on the contribution made by the 2004 Nobel Laureate from Kenya, Wangari Maathai, who won the Noble Prize for peace for her work in addressing the global environmental crisis. This article is based on a study of her written legacy. ${ }^{1}$ The hermeneutical lens of DGR is applied to

The works by Wangari Maathai that were consulted for the purposes of this study / article are as follows: "An Unbreakable Link: Peace, Environment, and Democracy," Harvard International Review 29, no. 4 (2008); "Nobel Peace Prize Speech: Nobel Lecture, Oslo, 10 December 2004," Meridians: Feminism, Race, Transnationalism 6, no. 1 (2005); Replenishing the Earth: Spiritual Values for Healing Ourselves and the World, (New York: Double Day Press, Random House, 2010); Unbowed. A Memoir (New York: Anchor Books, 2007). For the detailed study on which this article is based, see also Louisa Johanna du Toit, "Evaluating the Life of Wangari Maathai $(1940$ - 2011) using the Lens of Dark Green Religion" (Masters' diss, University of Johannesburg, 2019). 
demonstrate that environmental spirituality served as the foundation of her life and work. DGR is a phenomenon defined by Bron Taylor. It is an umbrella term encompassing nature revering movements in all areas of society that hold nature sacred and prioritizes the care and reverence for Mother Earth. ${ }^{2}$ Three principles are indicative of a DGR spirituality, namely belonging, interconnectedness, and sacredness. These principles are applied to the autobiography and other publications by and about Wangari Maathai, to support the notion that she embodied the spirituality of DGR. This analysis also proposes the type of DGR she most likely represents.

\section{Background}

\section{a) Wangari Maathai's Green Belt Movement - a response to environmental degradation in Kenya}

Wangari Maathai (April 1940 - September 2011), achieved recognition for the establishment of the GBM in $1977 .^{3}$ The movement arose as a response to the effect of environmental degradation on the lives of people, especially women, in rural areas of Kenya. Maathai who was awarded the Nobel Peace Prize in 2004 for the work achieved by the $\mathrm{GBM}^{4}$ was also active in other spheres. She advocated that an indivisible link exists between the environment, peace and democracy. She considered her Nobel Peace Prize as recognition of the importance of this indivisible link. ${ }^{5}$ In light of the mounting global environmental crisis $^{6}$ this recognition presented an important step.

2 Bron Taylor, Dark Green Religion: Nature Spirituality and the Planetary Future (Berkeley California: University of California Press, 2010), 13.

3 Wangari Maathai, Unbowed, 254-276, 291-295; Wangari Maathai, Replenishing the Earth, 13.

4 Wangari Maathai, "Nobel Peace Prize Speech," 195-201.

5 Wangari Maathai, "An Unbreakable Link, 24-27.

6 The global environmental crisis is the topic of worldwide research and according to the $5^{\text {th }}$ assessment report by the Intergovernmental Panel on Climate Change released in 2014, a limited time remains before the changes to the earth's ecosystems as a result of human exploitation will become irreversible and lead to a chain reaction of increasing magnitude, 
Members in country-wide communities, over a period of thirty years, ${ }^{7}$ planted 30 million indigenous trees in so-called Green Belts of up to 1000 trees and this resulted in the GBM. Through these unassuming and modest deeds of planting trees the GBM empowered women in rural parts of Kenya to improve their lives. ${ }^{8}$ The planting of such large numbers of trees was beneficial in reversing the effects of environmental degradation. Observations of the implementation of GBM projects revealed that becoming involved in the regeneration of their living environment positively impacted other aspects of people's lives, and in this case particularly that of women living in rural areas. ${ }^{9}$

Wangari Maathai did not found the GBM based on a specific religious denomination or spiritual creed. ${ }^{10}$ She acknowledged that specific spiritual or religious traditions did not inspire her work with the GBM, but that she tended to lean towards an ecumenical understanding of faith. ${ }^{11}$ GBM workers used concepts that were familiar to the communities where they worked. The use of biblical examples in the GBM, to explain how natural resources should be appreciated and utilized, ${ }^{12}$ was a fallout of the introduction of Christianity during the colonial occupation of Kenya. The GBM often also incorporated concepts from other religious traditions into the GBM values. ${ }^{13}$

the exact implications of which cannot be predicted. Jonathan Watts, "Global Warming must not Exceed $1.5^{\circ} \mathrm{C}$ warns Landmark UN report," The Guardian Weekly, October 2018, accessed May 7, 2019, https://www.theguardian.com/environment/2018/oct/08/globalwarming-must-not-exceed-15c-warns-landmark-un-report

7 Maathai, Unbowed, 137.

8 Maathai, Replenishing the Earth, 13.

9 Maathai, "An Unbreakable Link," 25. Lisa Merton and Alan Dater, "Taking Root: The Vision of Wangari Maathai," Directors' Statement, 2008, 2, accessed April 6, 2019, http://www.takingrootfilm.com/wp-content/uploads/2015/05/Taking-Root-DirectorsStatement.pdf

10 Maathai, Replenishing the Earth, 13.

11 Maathai, Replenishing the Earth, 14.

12 Maathai, Replenishing the Earth, 20.

13 Maathai, "An Unbreakable Link", 27; Maathai, Replenishing the Earth, 15. 
Maathai does not distinguish between 'spiritual' or 'secular' activities of the GBM. However, she realized over time that even the simple action of planting trees led to changes in people themselves. ${ }^{14}$ The involvement in caring for and regenerating their living environment allowed people to discover their own voices, increase their self-knowledge and develop selfconfidence - characteristics that are negatively affected by poverty and hopelessness. ${ }^{15}$

This realization that people's lives can be positively transformed by their involvement in regenerating their living environment motivated Maathai and the GBM to get involved with communities striving for justice and a democratic society. The movement therefore started to play a more public role in advocating for human, environmental, political and civic rights in Kenya. ${ }^{16}$ The GBM used a practical approach and thinking to solve environmental problems.

A key reason for the success and growth of the GBM was its dependence on specific core values. The founding values of the GBM are love for the environment; reverence for the earth's resources; a willingness to strive for self-empowerment and self-improvement; and a readiness to volunteer to help other people. ${ }^{17}$

\section{b) The global environmental crisis}

Humans cannot exist on Earth without impacting the environment. Changes in the environment as a result of human activities have been recorded throughout human history. ${ }^{18}$ However, the rate and impact of changes in the earth's environment as a result of scientific and technological advances have

\footnotetext{
14 Maathai, Replenishing the Earth, 14.

15 Merton and Dater, "Taking Root."

16 Maathai, Replenishing the Earth, 14.

17 Maathai, Replenishing the Earth, 14.

18 Lyn White, "The Historical Roots of our Ecologic Crisis," Science 155, no. 3767 (1967): 1203-1207.
} 
accelerated markedly of late. The impact is felt on a global scale. ${ }^{19}$ Although the exact effect of environmental changes brought about by human activities cannot be accurately predicted, there are some indications that signal it. The most recent scientific measurements of indicators of global warming confirm that deterioration is occurring faster than anticipated. These indicators include the increased concentrations of atmospheric carbon dioxide and methane gas; accelerated melting of the Greenland ice sheet, Arctic ice cap and Antarctic ice shelves; increased global average temperatures; and an alarming increase in the extinction of species (loss of biodiversity) that threatens food security globally. ${ }^{20}$

The continent of Africa is particularly susceptible to the effects of climate change. Areas that are currently experiencing food scarcity and the resulting famine will be further destabilized by increasing climate variability. Subsistence farmers in particular, will struggle more and more to adapt to unaccustomed seasonal variations in temperature and rainfall. ${ }^{21}$

The severity of the global environmental crisis has been underestimated and measures to combat the crisis have been hugely insufficient. Measures to reduce greenhouse emissions implemented by the United Nations is a case in point. ${ }^{22}$ Meanwhile, time to reverse the crisis is fast running out. The Intergovernmental Panel on Climate Change reports that the time remaining

19 Roger Gottlieb ed., The Oxford Handbook of Religion and Ecology (New York: Oxford University Press, 2006), 5.

20 Chris Engelbrecht, "At Death's Door," Power point slides for the talk posted on February 27, 2019 accessed from @UJLibrary· Library Facebook page, https://www.facebook.com/UJLibrary/videos/614262732377939/

21 Thomas Downing, "Vulnerability to Hunger in Africa: A Climate Change Perspective," Global Environmental Change 1, no. 5 (1991):365-380; Tim Wheeler, and Joachim von Braun, "Climate Change Impacts on Global Food Security," Science 341, no. 6145 (2013): 508-513.

22 Clare Breidenich, Daniel Magraw, Anne Rowley, and James W. Rubin. "The Kyoto Protocol to the United Nations Framework Convention on Climate Change," American Journal of International Law 92, no. 2 (1998): 315-331. 
to implement effective changes to limit global warming is about 12 years. ${ }^{23}$ These predictions are disturbing and overwhelming and give rise to contradictory opinions. One deduction, however, remains undisputed - the effects of human excess on the earth and our environment are clearly discernible and need to be addressed.

\section{c) The role of religion in the environmental crisis}

All humans have a vested interest in their own and the planet's survival. Humans are guided by religion and spiritual leaders. Therefore, religion has a role to play in human life, whether in policy making or in daily life. Religion is significant in affirming the connectedness of human life to nature and natural resources. Thus, religion, as an important thought-leader in human society, cannot remain aloof from the environmental crisis. Religions have been accused of being partly responsible for the severity of the planet's crisis. ${ }^{24}$ As guardians and guides of human societal norms, religious leaders have a responsibility to take a lead in addressing the crisis. ${ }^{25}$

Modern history provides a record of how progress and development were prioritized over the rights of other inhabitants of the earth and the earth herself. Part of the responsibility for the anthropocentric worldview that prevails in Western society has been ascribed to Christianity. ${ }^{26}$ Some Christian scholars like Norman Habel have attempted to change this worldview. As part of the Earth Bible Team, a reinterpretation of the Bible was undertaken using feminist hermeneutics of suspicion to expose anthropocentric biblical texts. ${ }^{27}$ The goal was to instil a sense of reverence for creation in readers of the Bible, and an acceptance of shared

23 Intergovernmental Panel on Climate Change, " $5^{\text {th }}$ Assessment Report (2014)," accessed May 13, 2019, https://www.ipcc.ch/assessment-report/ar5/; Watts, "Global warming must not exceed $1.5^{\circ} \mathrm{C} "$ White, "The Historical Roots," 1205; Taylor, Dark Green Religion, 10-11.

White, "The Historical Roots," 1206; Maathai, Replenishing the Earth, 147, 150.

White, "The Historical Roots," 1205-1206.

27 Norman Habel, ed., Readings from the Perspective of Earth Volume 1 (Sheffield: Sheffield Academic Press, 2000), 7. 
responsibility. For this purpose, a set of eco-justice principles were formulated. ${ }^{28}$ An environmentally friendly worldview from a Christian perspective, according to Habel, can be expressed as follows:

Earth is a living planet that originated in cosmic space and evolved into a living habitat; Earth is a fragile web of interconnected and interdependent forces and domains of existence; Earth is a living community in which humans and all other organisms are kin, who live and move and have their common destiny. ${ }^{29}$

Such attempts by Christian scholars had a limited impact and have not served to undo the heavily anthropocentric worldview undergirding Christian beliefs.

\section{Dark Green Religion}

Greening of Christianity from within, however, did not achieve the desired response. The acceptance of an environmentally friendly worldview by the majority of Christian devotees has not yet occurred. Consequently, more and more nature revering movements that are detached from recognized religious systems, have been emerging worldwide. ${ }^{30}$ This phenomenon of nature revering movements has been extensively researched by Bron Taylor who labelled it Dark Green Religion. ${ }^{31}$

According to Taylor, adherents of DGR do not regard care of the environment purely as a moral obligation but have a passionate affection for nature and consider it to be sacred and deserving of reverent care. ${ }^{32}$ DGR is distinguished by a kinship that incorporates all living organisms and renounces human superiority. There is also a focus on interconnectedness

\footnotetext{
28 Habel, Readings, 16.

29 Norman Habel, An Inconvenient Text: Is a Green Reading of the Bible possible?

(Hindmarsh: Australasian Theological Forum Press, 2009), 43.

30 Taylor, Dark Green Religion, 11-12.

31 Taylor, Dark Green Religion. 10-13.

32 Taylor, Dark Green Religion, 10.
} 
and interdependence, a realization that is informed by scientific knowledge from various disciplines such as ecology and physics. ${ }^{33}$

\section{The possible role of Dark Green Religion in promoting an alternative worldview}

There are a range of movements that could fall under the DGR umbrella, Taylor distinguishes four types of DGR. They are: Spiritual Animism, Naturalistic Animism, Gaian Spirituality, and Gaian Naturalism (Gaian Earth Religion). The separations between these types are not definite and overlaps between the different types of DGR exist. ${ }^{34}$

Spiritual Animism refers to the conferring of supernatural powers to specific natural objects or living entities. Spiritual animism believes that these entities possess some form of consciousness and should be revered. ${ }^{35}$ Deep Ecology ${ }^{36}$ is a concept related to this type of spirituality that reveals a more holistic worldview.

Naturalistic Animism is a belief system without any supernatural connotations. It is based on a yearning to relate to and understand nature in all its manifestations and leads to a respectful and harmonious relationship with other living organisms. ${ }^{37}$

Gaian Spirituality and Gaian Naturalism are based on the concept of Gaia, the living Earth goddess. ${ }^{38}$ This perception regards the whole biosphere as

\footnotetext{
33 Taylor, Dark Green Religion, 13.

Taylor, Dark Green Religion, 15.

Fikret Berkes, Sacred Ecology (New York: Routledge, 2008), 11.

Deep Ecology refers to the addition of ethical and spiritual components to the science of ecology, producing an interconnected and relational perspective on the environment.

Berkes, Sacred Ecology, 2.

37 Taylor, Dark Green Religion, 15.

38 Bron Taylor, "Religion and Environmentalism in America and Beyond," in The Oxford Handbook of Religion and Ecology, ed. Roger Gottlieb (New York: Oxford University Press, 2006), 595; Berkes, Sacred Ecology, 2, 275.
} 
one self-sustaining system. It is an expression of the DGR principle of interconnectedness and can also be referred to as organicism. ${ }^{39}$

Gaian Spirituality is the belief that the biosphere is a conscious supernatural being which should be revered and held sacred. It contains an element of pantheism. The belief in the supernatural links this type of DGR with Spiritual Animism. ${ }^{40}$

Gaian Naturalism, however, does not incorporate a belief in the supernatural, similar to Naturalistic Animism. Gaian Naturalism still incorporates a pantheistic reverence towards Gaia, the earth, but combines it with scientific knowledge regarding living eco-systems and their interactions. ${ }^{41}$

The four types of DGR outlined above illustrate how diverse belief systems can be interrelated, allowing them to merge into the phenomenon of Dark Green Religion.

Though it might seem unfamiliar, the essence of DGR is present around us in various guises. A brief examination of the topics of popular films, books, music and poetry reveals aspects of DGR, directly or indirectly. World leaders also reflect aspects of DGR in their media releases, an example being the well-known documentary, An Inconvenient Truth, released in 2006 by the then vice-president of the USA, Al Gore. ${ }^{42}$

\footnotetext{
39 Taylor, Dark Green Religion, 16.

40 Taylor, Dark Green Religion, 16.

41 Berkes, Sacred Ecology, 114.

42 John Rafferty, "An Inconvenient Truth: 10 Years hence", 2016, accessed January 16, 2019, www.britannica.com/story/an-inconvenient-truth-10-years-hence
} 


\section{Evidence of the principles of Dark Green Religion in the life of Wangari Maathai}

Wangari Maathai is an excellent example of a world leader promoting a change in worldview and supporting it by her actions.

\section{a) A growing environmental awareness}

The autobiography of Wangari Maathai, Unbowed: A Memoir (2007), provides the reader with a vivid account of Maathai's early childhood in rural Kenya. ${ }^{43}$ She recounts how her love for and association with nature was nurtured. At that time the land was fertile, and people could cultivate sufficient food to provide for their needs. ${ }^{44}$ Her childhood years were spent under colonial rule and she witnessed the deterioration taking place in the environment due to exploitative agricultural practices. The land was denuded of trees. This, in combination with other consequences of commercial farming, resulted in the deterioration of the environment. The extent of the degeneration of the environment within just one generation was such that subsistence farmers could no longer survive. ${ }^{45}$

Maathai also grew up with the Kikuyu tradition of evening storytelling, which was how knowledge was transferred from one generation to the next. ${ }^{46}$ The stories helped children to develop a sense of identity and belonging, while simultaneously imbibing the foundations of African traditional religion as part of their daily lives. Stories instilled in youth an appreciation for the knowledge of their people as they learned to live in harmony with the land around them. ${ }^{47}$

These cultural practices were replaced when Christian missionaries introduced Western concepts into the Kikuyu culture. People lost their sense

\footnotetext{
43 Maathai, Unbowed, 2-3.

44 Maathai, Unbowed, 4.

45 Maathai, Unbowed, 37-39.

46 Maathai, Unbowed, 5.

47 Maathai, Unbowed, 5.
} 
of identity and developed a disregard for their environment. ${ }^{48}$ Colonial rulers promoted the use of English, instead of African languages, and renamed landmarks. This further confused and disrupted people's development of a sense of belonging. ${ }^{49}$

However, colonial practices did not compel Maathai to lose her love for her mother tongue and her traditions ${ }^{50}$ - factors contributing to the success of the GBM in obtaining the support of rural communities. ${ }^{51}$

\section{b) Indications of the principle of belonging}

The principle of belonging refers to a sincere belief that the earth is our home and humans belong and derive our personal well-being from this connection. ${ }^{52}$ The principle of belonging can be discerned in various facets of the life of Wangari Maathai. As already mentioned, her African traditions were a major influence in her life. These included the Kikuyu rituals at the birth of her children; ${ }^{53}$ the naming of her children after relatives; ${ }^{54}$ the changes to her own name; 55 the tradition of storytelling which was often used by Maathai when speaking in public; ${ }^{56}$ and the maintaining of her family ties. $^{57}$

The relationship with her mother was especially important to Wangari Maathai. This strong bond enabled her to relate to the problems experienced

\footnotetext{
48 Maathai, Unbowed, 6.

49 Maathai, Unbowed, 11, 60.

50 Maathai, Unbowed, 60, 71.

51 Maathai, Unbowed, 174.

52 Hendrik Viviers, "Is Psalm 104 an Expression (also) of Dark Green Religion?" HTS Teologiese Studies/ Theological Studies 73, no. 3 (2017): 4, a3829. https://doi. org/10.4102/hts.v73i3.3829.

53 Maathai, Unbowed, 7.

54 Maathai, Unbowed, 49, 112.

55 Maathai, Unbowed, 96, 147.

56 Maathai, Unbowed, 50; Kathleen Hunt, “'It's more than Planting Trees, it's Planting Ideas": Ecofeminist Praxis in the Green Belt Movement," Southern Communication Journal 79, no. 3 (2014): 235.

57 Maathai, Unbowed, 13, 274-276).
} 
by rural women living in a degraded environment. ${ }^{58}$ This connection between rural African women, who are directly affected by the condition of their environment, and social justice, was the starting point that led Maathai to engage with authorities. ${ }^{59}$

The actions initiated by Maathai and the GBM against social injustice and corruption, as well as decisions negatively affecting the environment, resulted in conflict between her and the government. ${ }^{60}$

Wangari Maathai's commitment to her African roots translated into actions to protect the environment, to enable future generations to continue living sustainably. This is evidence of the principle of belonging. In her Nobel Peace Prize acceptance speech, she emphasizes this: "Africans, especially, should re-discover positive aspects of their culture. In accepting them, they would give themselves a sense of belonging, identity and self-confidence". ${ }^{61}$

\section{c) Indications of the Principle of interconnectedness}

The principle of interconnectedness is based on the reality that all life on Earth is connected and interrelated in some or other way and shares the same resources. ${ }^{62}$ The principle of belonging or kinship discussed previously forms part of this recognition of the interconnectedness of life on Earth. Interconnectedness refers to the connections that exist between all humans, but also extends to other living organisms, for example trees.

58 Maathai, Unbowed, 123-125.

59 Maathai, "Nobel Peace Prize speech," 2; "An Unbreakable Link," 25.

60 Her campaigns for democratic governance and sustainable environmental practices provoked harsh responses from the Kenyan government but that did not deter her. Maathai, Unbowed, 179-183; "An Unbreakable Link," 24; A well-known incident took place at Freedom Corner in Nairobi. There a protest against detention of political activists without trial was held by the mothers of the prisoners and by Wangari Maathai herself. She remarks: "The story of Freedom Corner did not end with my hospitalization or the dispersal of the mothers. We remained unbowed." (222), which became the title of her autobiography Unbowed: A Memoir, 2007.

61 Maathai, "Nobel Peace Prize speech," 3.

62 Viviers, "Psalm 104 an Expression of Dark Green Religion?" 6. 
From a very young age Maathai loved cultivating the fields and planting crops with her mother. During this process, she observed the interdependence between the soil, plants, insects such as bees and butterflies, and the birds that came and ate the seeds. ${ }^{63}$ Even after moving away to attend school, she returned during holidays to help her mother cultivate the fields and harvest the crops. ${ }^{64}$

Trees played a large role in the life of Wangari Maathai, and one specific fig tree features in some of her cherished childhood memories. Her mother taught her that fig trees are sacred and should always be left undisturbed. ${ }^{65}$ As a small child, she used to play at the foot of a huge fig tree with a stream bubbling out from under its roots. In the stream among the plants growing there, she played with the frogs' eggs and tadpoles. ${ }^{66}$ Her scientific education later enabled her to understand the interdependence between the various components of ecosystems. She also realized that the traditional knowledge of her people acknowledged this interdependence and protected it. ${ }^{67}$ The significance of Kikuyu traditional knowledge was brought home to her in a stark manner when she returned as an adult to the area where she used to play and found the tree cut down and the stream dried up. ${ }^{68}$

During her university career, Maathai was required to do research on cattle diseases, and became aware how undernourished not only the animals, but also the people of the rural areas had become. It indicated a decrease in the yield from the once fertile fields and illuminated some of the problems faced by women in rural areas. These problems became the focus of the National Council of Women of Kenya (NCWK). ${ }^{69}$

\footnotetext{
63 Maathai, Unbowed, 37-38.

64 Maathai, Unbowed, 47-48.

65 Maathai, Unbowed, 45.

66 Maathai, Unbowed, 45.

67 Maathai, Unbowed, 46, 122.

68 Maathai, Unbowed, 121-122.

69 Maathai, Unbowed, 123-124.
} 
Maathai concluded that the undernourishment she observed was as a result of a diet lacking in nutrients and that it was linked to a shortage of firewood. Trees were removed to provide space for commercial farming and indigenous forests were replaced with plantations of exotic trees. ${ }^{70}$ This resulted in less wood being available for household use. Women prepared foods that required less cooking or reverted to more processed foods and as a result, people became undernourished. ${ }^{71}$ The fields also did not yield as abundantly as before due to exhaustion of the soil. ${ }^{72}$

The realization that the environment had deteriorated, in just one generation, such that people could no longer sustain themselves, and that this deterioration would affect all future generations including herself and her children, ${ }^{73}$ motivated Maathai to find a solution. The solution was to plant indigenous trees. These trees would address the problems faced by rural people, particularly rural women, on more than one level. The natural ecosystems would be restored by the trees providing a habitat for birds, plants, insects and animals; the trees would nourish and enrich the soil; the trees would improve water retention and prevent erosion by binding the soil with their roots; the trees would provide food for humans and animals; the trees would provide shade; and the trees would provide firewood. From this idea, the GBM was born. ${ }^{74}$

In her speech when accepting the Nobel Peace Prize, Maathai says that:

Women did not realize that meeting their needs depended on their environment being healthy and well managed. They were unaware that a degraded environment leads to a scramble for scarce resources and may culminate in poverty and even conflict. They were also unaware of the injustices of international economic arrangements. ${ }^{75}$

\footnotetext{
70 Maathai, Unbowed, 38-39.

71 Maathai, Unbowed, 123.

72 Maathai, Unbowed, 121.

73 Maathai, Unbowed, 125.

74 Maathai, Unbowed, 125.

75 Maathai, "Nobel Peace Prize speech", 2.
} 
This statement reiterates the interconnectedness between people, their environment and their personal well-being.

\section{d) Indications of the Principle of sacredness}

The word sacred means that something or someone is above or apart from the ordinary. ${ }^{76}$ In terms of DGR, the term sacred implies the possession of intrinsic worth, and describes the feelings of awe and wonder experienced when faced with the beauty and grandeur of creation. ${ }^{77}$ This principle opposes the utilitarian worldview that only considers the material worth and profit potential of the earth and her resources. The DGR principle of sacredness links directly with religion as revealed by the language used to describe it. ${ }^{78}$

The title of her work, Replenishing the Earth: Spiritual Values for Healing Ourselves and the World (2010), ${ }^{79}$ confirms that spiritual values are at the core of the work of the GBM and formed the foundation of Maathai's personal vision. In this book, she elaborates on the core values underlying the GBM and describes how the beauty and wonders of nature inspire feelings of wonder and awe in people, a confirmation of the DGR principle of sacredness in her life.

According to Maathai, the earth should be preserved, protected and respected and she urges all earth's inhabitants to participate in this. Her own words powerfully express this: "The future of the planet concerns all of us, and all of us should do what we can to protect it"80... "As women and men continue this work of clothing this naked Earth, we are in the company of

\footnotetext{
76 Mircea Eliade, ed., The Encyclopedia of Religion (New York: MacMillan, 1987), 282.

77 Taylor, Dark Green Religion, 12; Viviers, "Psalm 104 an Expression of Dark Green Religion?" 7.

78 Eliade, The Encyclopedia of Religion, 282, 284.

79 Maathai, Replenishing the Earth.

80 Maathai, Unbowed, 138.
} 
many others throughout the world who care deeply for this blue planet. We have nowhere else to go". ${ }^{81}$

Maathai makes little reference to her personal relationship with religion, but the language she uses to refer to nature displays her reverence for the earth and her resources. Her references to Mount Kenya are examples of this: "I faced Mt Kenya, the source of inspiration for me throughout my life, as well as for generations of people before me"; 82 and "At that moment I felt I stood on sacred ground". 83

Maathai acknowledges that she adopted an ecumenical approach to religion, ${ }^{84}$ and as already discussed, admits that her African traditions and culture played a large role in her life. Therefore, in interaction with communities, the GBM makes use of knowledge from the Kikuyu tradition as well as practices with a Judeo-Christian origin. ${ }^{85}$ Concepts from other religious traditions are also included, such as the concept of mottainai, from an Eastern religious perspective ${ }^{86}$ that promotes respect and gratitude for the earth's resources. Maathai's ecumenical approach supports the view that her main motivation was to care for the earth and to encourage all other people to join her in that mission. She views the earth as possessing intrinsic worth and as being worthy of care, protection and respect. ${ }^{87}$ This is a reflection of the DGR principle of sacredness.

\section{e) The symbolism of trees}

Trees are considered as a symbol of life because of their ability to regenerate. They represent youth, immortality and wisdom. ${ }^{88}$ Throughout

\footnotetext{
81 Maathai, Unbowed, 295.

82 Maathai, Unbowed, 292-293.

83 Maathai, Unbowed, 293.

84 Maathai, Replenishing the Earth, 20.

85 Maathai, Replenishing the Earth, 20.

86 Maathai, "An Unbreakable Link", 27; Maathai, Replenishing the Earth, 15.

87 Maathai, Unbowed, 138, 295.

88 Mircea Eliade, The Sacred and the Profane: The Nature of Religion (Houghton Mifflin: Harcourt, 1959), 149.
} 
the history of humankind, trees have been part of religious ritual and are imbued with sacredness. ${ }^{89}$ Trees also form part of African traditional religion and sacred practices involving trees are found in various communities all over the continent. ${ }^{90}$

The GBM promoted the planting of trees as a way of regenerating the environment, but Maathai remarks that "Trees are living symbols of peace and hope." 91 Thus, she acknowledges that trees have ecological as well as spiritual value.

Maathai planted trees to commemorate important occasions, ${ }^{92}$ a technique that became characteristic of the GBM and one that was used as a method of peaceful environmental activism by communities. ${ }^{93}$ The actions of the GBM also focus on the preservation and recreation of forests through the planting of Green Belts of trees. ${ }^{94}$ Maathai believed that forests played an important role in healing the wounds inflicted on the earth and therefore considered them very important. ${ }^{95}$

\section{f) Gaian Naturalism}

In the preceding explanation of DGR, it was mentioned that the phenomenon of DGR can be discerned as four different types of spirituality. Gaian Naturalism is a personal belief system that reveres the earth without any supernatural connotations, in combination with ecological scientific knowledge. ${ }^{96}$ From the discussion about Wangari Maathai and the evidence of the principles of DGR in her life, it may be concluded that her spirituality resembles that of Gaian Naturalism. Her spiritual value system is closely

\footnotetext{
89 Eliade, The Encyclopedia of Religion, 1661.

90 Maathai, Replenishing the Earth, 81.

91 Maathai, Unbowed, 293.

92 Maathai, Unbowed, 228, 292, 306.

93 Maathai, Unbowed, 131, 167; Maathai, Replenishing the Earth, 96.

94 Maathai, Unbowed, 273.

95 Maathai, Unbowed, 173.

96 Berkes, Sacred Ecology, 114.
} 
bonded with an overarching reverence and concern for the earth and her inhabitants.

\section{A link between ecofeminism and Dark Green Religion}

The term ecofeminism is a combination of the words ecology and feminism. Ecology is the study of the oikos or household of earth and the relationships that binds all members of the household together, ${ }^{97}$ and feminism is seen as being different from the accepted (masculine or patriarchal) norm and questioning the status quo. ${ }^{98}$ The term ecofeminism was first used by Francoise d'Eubonne in a publication in 1974 and has since been considered as either a wave of feminism or a manifestation of Deep Ecology. ${ }^{99}$ (see also Footnote 39).

As discussed previously, the phenomenon of DGR is characterized by the three principles of belonging, interconnectedness and sacredness. These principles are also important concepts of ecofeminism. The holistic thinking promoted by ecofeminism is grounded in ecological principles instead of a dualistic view of life and strives towards interconnectedness between human genders and between humans and nature. ${ }^{100}$ The lack of an alternative home means that sustainability is our only future, a founding tenet of ecofeminism. ${ }^{101}$ DGR promotes this same interconnectedness, derived from a holistic ecological point of view. ${ }^{102}$ In the work of Wangari Maathai with the GBM, trees functioned as living examples of interconnectedness and

\footnotetext{
97 Jytte Nhanenge, "Ecofeminism: Towards Integrating the Concerns of Women, Poor People and Nature into Development" (Master's diss, UNISA, 2007), 120.

98 Nhanenge, "Ecofeminism: Towards Integrating the Concerns of Women," 98.

99 Laura Hobgood-Oster, "Ecofeminism - Historic and International Evolution," in The Encyclopedia of Religion and Nature, ed. Bron R Taylor (London: Thoemmes, 2005), 533.

100 Nhanenge, "Ecofeminism: Towards Integrating the Concerns of Women," 114; HobgoodOster, "Ecofeminism evolution", 534.

101 Nhanenge, "Ecofeminism: Towards Integrating the Concerns of Women," 412.

102 Viviers, "Psalm 104 an Expression of Dark Green Religion?" 6.
} 
changed both the environment and people's lives, in particular, that of rural African women. ${ }^{103}$

The principle of interconnectedness is closely linked to that of sacredness, in that it focuses on the one Earth that is our home and our only refuge. ${ }^{104}$ Ecofeminism has a strong spiritual component and often interacts with interreligious dialogues, and links with feminist interpretations of sacred texts. ${ }^{105}$ The movement's promotion of respect and reverence for the earth as the foundation for the survival of humanity ${ }^{106}$ provides proof of the sacredness that nature is regarded with. ${ }^{107}$ Based on the acceptance of Mother Earth as our home, belonging is the remaining principle of DGR that is interwoven with the other two (interconnectedness and sacredness). ${ }^{108}$ In Wangari Maathai's life, evidence of this principle is found in her appreciation of her African roots and culture. ${ }^{109}$

In the prior sections of this article, I attempted to provide proof of the principles of DGR in the life and work of Wangari Maathai; but as indicated above, these principles can likewise be found in the concept of ecofeminism as well. Therefore, Wangari Maathai can be viewed as an eco-feminist, based on her role as a social activist in pursuing social justice for women as well as environmental justice. ${ }^{110}$

\section{Conclusion}

A discussion of the environment we live in and the deteriorating condition of the earth and her interlinked eco-systems inevitably leads to the deduction that the effects of human excess on the earth and our environment are

\footnotetext{
103 Gathuru Mburu, "Kenya Green Belt Movement," in The Encyclopedia of Religion and Nature, ed. Bron R Taylor (London: Thoemmes, 2005), 957.

104 Nhanenge, "Ecofeminism: Towards Integrating the Concerns of Women," 558.

105 Hobgood-Oster, "Ecofeminism - Historic and International Evolution", 537.

106 Nhanenge, "Ecofeminism: Towards Integrating the Concerns of Women," 558.

107 Nhanenge, "Ecofeminism: Towards Integrating the Concerns of Women," 558.

108 Viviers, "Psalm 104 an Expression of Dark Green Religion?" 4.

109 Maathai, Unbowed, 60, 71, 174.

110 Mburu, "Kenya Green Belt Movement," 957.
} 
clearly discernible and need to be addressed. Only a unified response from all sectors of human society would have the potential to positively impact environmental degradation. This article attempted to examine the underlying principles holding together the life of a person who dedicated her life to respond to environmental degradation, namely, Wangari Maathai, the Nobel Peace Prize winner of 2004.

This study of Wangari Maathai's written legacy provides evidence of the presence of the DGR principles of belonging, interconnectedness and sacredness in her life. I conclude that she may be considered a proponent of the Dark Green Religion and that her spirituality may be viewed as Gaian Naturalism, one of the four types of the DGR.

Viewing Wangari Maathai's life through the hermeneutical lenses of DGR provides support for the promotion of DGR as a forum that could unite nature revering movements and formulate a unified response to the environmental crisis. A unified response could, in turn, promote a change in worldview among human beings and accelerate the adoption of an environmentally sustainable lifestyle. An environmentally sustainable lifestyle could significantly contribute to the reversal of the degradation of the environment and ease the global crisis.

Maathai's reverence and concern for the earth and all her inhabitants resulted in admirable perseverance and commitment in attempting to restore the environment of her country. Wangari Maathai is an example to all of us. She made any sacrifice necessary to reach her goal of restoring the environment, and in the process made a significant contribution.

\section{References}

Berkes, Fikret. Sacred Ecology. New York: Routledge, 2008.

Breidenich, Clare, Daniel Magraw, Anne Rowley, and James W. Rubin. "The Kyoto Protocol to the United Nations Framework Convention on Climate Change." American Journal of International Law 92, no. 2 (1998): 315-331. 
Du Toit, Louisa Johanna. "Evaluating the Life of Wangari Maathai (1940 2011) using the Lens of Dark Green Religion." Master's Diss., University of Johannesburg, 2019.

Downing, Thomas E. "Vulnerability to Hunger in Africa: A Climate Change Perspective." Global Environmental Change 1, no. 5 (1991): 365-380.

Eliade, Mircea. The Sacred and the Profane: The Nature of Religion. Houghton Mifflin: Harcourt, 1959.

Eliade, Mircea, ed. The Encyclopedia of Religion, 282-283. New York: MacMillan, 1987.

Engelbrecht, Chris. "At Death's Door," Power point slides for the talk posted on February 27, 2019 accessed from @UJLibrary · Library Facebook page, https://www.facebook.com/UJLibrary/videos/614262732377939/

Gottlieb, Roger S, ed. The Oxford Handbook of Religion and Ecology. New York: Oxford University Press, 2006.

Habel, Norman, ed. Readings from the Perspective of Earth (Vol. 1). Sheffield: Sheffield Academic Press, 2000.

Habel, Norman. An Inconvenient Text: Is a Green Reading of the Bible Possible? Hindmarsh: Australasian Theological Forum Press, 2009.

Hobgood-Oster, Laura. "Ecofeminism - Historic and International Evolution." In The Encyclopedia of Religion and Nature, edited by Bron R Taylor, 533538. London: Thoemmes, 2005.

Hunt, KP. "It's More than Planting Trees, it's Planting Ideas: Ecofeminist Praxis in the Green Belt Movement." Southern Communication Journal 79, no. 3 (2014): 235-249.

Intergovernmental Panel on Climate Change. 2014. "5th Assessment Report (2014)". Accessed May 13, 2019. https://www.ipcc.ch/assessmentreport/ar5/ 
Maathai, Wangari. "An Unbreakable Link: Peace, Environment, and Democracy." Harvard International Review 29, no. 4 (2008): 24-27.

Maathai, Wangari. "Nobel Peace Prize Speech: Nobel Lecture, Oslo, 10 December 2004." Meridians: Feminism, Race, Transnationalism 6, no. 1 (2005): 195-201.

Maathai, Wangari. Replenishing the Earth: Spiritual Values for Healing Ourselves and the World. New York: Double Day Press, Random House, 2010.

Maathai, Wangari. Unbowed. A Memoir. New York: Anchor Books, 2007.

Mburu, Gathuru. "Kenya Green Belt Movement." In The Encyclopedia of Religion and Nature, edited by Bron R Taylor, 957-961. London: Thoemmes, 2005.

Merton, Lisa and Dater, Alan. "Taking Root: The Vision of Wangari Maathai." Directors' Statement, 2008. Accessed April 6, 2019. http://www.takingrootfilm.com/wp-content/uploads/2015/05/Taking-Root-

\section{Directors-Statement.pdf}

Nhanenge, Jytte. "Ecofeminism: Towards integrating the concerns of women, poor people and nature into development." Master's Diss., UNISA, 2007.

Rafferty, John. An Inconvenient Truth: 10 Years hence. 2016. Accessed on January 16, 2019. www.britannica.com/story/an-inconvenient-truth-10years-hence

Taylor, Bron. Dark Green Religion: Nature Spirituality and the Planetary Future. Berkeley California: University of California Press, 2010.

Taylor, Bron. "Religion and Environmentalism in America and beyond." In The Oxford Handbook of Religion and Ecology, edited by Roger Gottlieb, 595. New York: Oxford University Press, 2006. 
Viviers, Hendrik. "Is Psalm 104 an Expression (also) of Dark Green Religion?" HTS Teologiese Studies/ Theological Studies, 73, no. 3(2017), a3829. https://doi. org/10.4102/hts.v73i3.3829.

Watts, Jonathan. "Global Warming must not Exceed $1.5 \circ \mathrm{C}$ warns Landmark UN Report." The Guardian Weekly, October 2018. Accessed May 7, 2019. https://www.theguardian.com/environment/2018/oct/08/global-warmingmust-not-exceed-15c-warns-landmark-un-report

Wheeler, Tim, and Joachim von Braun. "Climate Change Impacts on Global Food Security.” Science, 341(2013), no. 6145: 508-513.

White, Lyn. "The Historical Roots of our Ecologic Crisis. Science, 155(1967), no. 3767: 1203-1207. 